\title{
The effect of dietary lipid saturation and antioxidant source on the nutrient digestibility of lamb finishing diets
}

\author{
K.E. Booyens ${ }^{1}$, O.B. Einkamerer ${ }^{1 \#}$, H.J. van der Merwe ${ }^{1}$, A. Hugo ${ }^{2}$, S.C. Slippers $^{3}$ \& \\ M.D. Fair ${ }^{1}$ \\ ${ }^{1}$ Department of Animal, Wildlife and Grassland Sciences; ${ }^{2}$ Department of Microbial, Biochemical and Food \\ Biotechnology; ${ }^{1,2}$ Faculty of Natural and Agricultural Sciences, University of the Free State, P.O. Box 339, \\ Bloemfontein 9300, South Africa; ${ }^{3}$ Meadow Feeds, P.O. Box 6224, Weltevreden Park 1715, South Africa
}

(Received 30 September 2012; Accepted 20 February 2013; First published online 2 June 2013)

\begin{tabular}{c} 
Copyright resides with the authors in terms of the Creative Commons Attribution 2.5 South African Licence. \\
See: http://creativecommons.org/licenses/by/2.5/za \\
$\begin{array}{c}\text { Condition of use: The user may copy, distribute, transmit and adapt the work, but must recognise the authors and the South African Journal of } \\
\text { Animal Science. }\end{array}$ \\
\hline
\end{tabular}

\begin{abstract}
The influence of a synthetic or natural antioxidant and lipid saturation on the apparent digestibility of nutrients in a standard lamb finishing diet was investigated. The four dietary treatments consisted of the same basal diet, providing 187 g CP-, 355 g NDF- and 71 g EE per kg DM, but differing in supplemental lipid source ( $30 \mathrm{~g} / \mathrm{kg}$ of either saturated beef tallow or unsaturated soybean oil) and type of antioxidant included (125 g/ton of either a synthetic or natural antioxidant). The digestibility study was conducted over a period of 12 days (including a 4-day adaptation to the faecal collection bags). Twenty-eight S.A. Mutton Merino lambs $(45.1 \pm 3.0 \mathrm{~kg})$ were randomly allocated to the four dietary treatments $(\mathrm{n}=7 \mathrm{lambs} /$ treatment). Composite feed, feed refusal and faecal samples of individually penned lambs were collected for chemical analysis. The apparent digestibility coefficients, digestible nutrient and available energy content were calculated accordingly. The DMI of the lambs did not differ significantly between the various experimental diets. The inclusion of unsaturated soybean oil reduced the apparent digestibility of NDF in the diet. The apparent digestibility of NDF seems to be higher when a natural antioxidant was included in the diet. The comparatively negative effects of the unsaturated lipid source and synthetic antioxidant on the apparent digestibility of NDF were associated with a significantly lower digestible NDF content in the experimental diet. Accordingly, soybean oil resulted in a significantly lower ME content in the diet. However, estimating $\mathrm{ME}$ from DE with a constant factor of 0.8 probably underestimates the ME content of diets supplemented with lipids rich in unsaturated fatty acids. The latter are known to reduce methane production, and hence, energy losses.
\end{abstract}

Keywords: Beef tallow, fatty acid, flavonoid, methane, soybean oil

\# Corresponding author: Einkamererob@ufs.ac.za

\section{Introduction}

Although primary feed sources for ruminants contain lipids, its content can be increased by fat or oil supplements. The lipid content of concentrates is usually higher than that of forages, and the majority is present in the form of triglycerides (Bauman et al., 2003).

Lipid is an energy component in ruminant diets and contains on average 2.25 times more energy than carbohydrates (McDonald et al., 2002). Nevertheless, added fats and oils in ruminant diets may negatively affect voluntary feed intake and nutrient digestibility (Coppock \& Wilks, 1991). Supplementing ruminant diets to have more than 6\% lipid (on a DM-basis) may decrease fibre digestion and methane $\left(\mathrm{CH}_{4}\right)$ production in vitro (Harris, 2003). This can be explained by physical coating of the fibres with a film of lipid, and by direct inhibition of rumen microbial activity (Palmquist \& Jenkins, 1980). Unsaturated fatty 
acids (UFA) appear to have a more pronounced adverse effect on rumen fermentation than saturated fatty acids (SFA) (Bauman et al., 2003). However, increasing concentrations of SFA in dietary lipid decreases rumen lipolysis, thus increasing the duodenal flow of triglycerides and decreasing total tract lipid digestibility (LaBrune et al., 2008).

Since UFAs are vulnerable to oxidative degeneration, antioxidants are added to diets to help prevent this process (Smith et al., 2007). Lipids possess a certain degree of resistance to oxidation, owing to the presence of natural antioxidants, for example fat soluble vitamin E, which protects lipid by preferential acceptance of free radicals (McDonald et al., 2002). A bias towards natural product alternatives is an emerging consumer-led trend that extends to antioxidants, informed by public health concerns and consequent regulatory restrictions about food use (e.g. a ban on etoxyquin in the European Union). Hence, there is increasing interest in the properties of naturally occurring antioxidants (Haak et al., 2006), such as flavonoids, which are secondary plant metabolites derived from phenylalanine and acetyl co-enzyme A (Winkel-Shirley, 2001) that act as antioxidants (Ross \& Kasum, 2007). Furthermore, some authors mentioned that adding flavonoids and phenolic compounds (i.e. plant derived tannins; Vasta et al., 2010) to ruminant feeds may alter microbial populations and consequently could affect ruminal $\mathrm{pH}$ (increasing lactate-consuming microorganisms; Balcells et al., 2012), DM intake and apparent nutrient digestibility (Jami et al., 2012). Consequently, flavonoids may act not only as natural antioxidants, but could also be considered as ruminal modifiers.

The aim of this study was therefore to determine the effects of fatty acid saturation and a bioflavonoid antioxidant on nutrient digestibility and the digestible nutrient content of finishing diets fed to lambs.

\section{Materials and Methods}

All procedures applied during this study were approved by the Interfaculty Animal Ethics Committee for Animal Experimentation at the University of the Free State (Animal Experiment No. 04/2010).

Twenty-eight S.A. Mutton Merino wether lambs weighing $45.1 \pm 3.0 \mathrm{~kg}$ were randomly allocated to four dietary treatments ( $\mathrm{n}=7$ lambs/treatment). Lambs were housed individually in pens. The four dietary treatments consisted of the same basal diet [187 g crude protein (CP), $355 \mathrm{~g}$ neutral detergent fibre (NDF), and $71 \mathrm{~g}$ ether extract (EE)/kg dry matter (DM)] only differing in the supplementary lipid source (30 $\mathrm{g} / \mathrm{kg}$ of either saturated beef tallow or unsaturated soybean oil) and type of antioxidant included (synthetic antioxidant included at $125 \mathrm{~g} /$ ton according to the supplier's instructions for use, and a natural antioxidant, also included at $125 \mathrm{~g} /$ ton for a direct comparison with the synthetic antioxidant). The synthetic antioxidant contained a combination of butylated hydroxyanisole (BHA), butylated hydroxytoluene (BHT), ethoxyquin, and trisodium citrate. The natural antioxidant is a polyphenolic plant extract containing bioflavonoids (cathecin and gallo-catchecin) and pro-anthocyanidins (which generate the anthocyanidins delfinidin, robinetidin and fisetidin). The digestibility study was conducted over a period of 12 days (4-day adaptation to the faecal collection bags followed by a consecutive 8-day collection period). No feed adaptation was necessary as lambs were randomly selected for the digestibility study at termination of a production study and fed the same respective treatment diets. Fresh, clean water was freely available.

To minimise variation in assessing the voluntary feed intake, a sequential method of feed allocation was followed by providing each lamb with a 15\% refusal level of intake. Feed offer calculations were done daily, based on the moving average feed intake of the preceding three days. The lambs were fed twice daily (at 07:15 and 15:45). The faeces voided were collected twice daily. Daily composite feed and feed refusals (orts) of each animal were also collected. After thorough mixing, representative samples were obtained by means of the quartering method (McDonald et al., 2002). Feed, orts and faecal samples were analysed for DM and CP content according to official methods for chemical analysis (AOAC, 2000). NDF (Van Soest et al., 1991) and gross energy (GE) (Cantrell et al., 2010) were also determined. The apparent digestibility, digestible nutrient and available energy content were calculated accordingly. The metabolizable energy (ME) content was estimated from digestible energy (DE) by applying the conversion factor of 0.8 (McDonald et al., 2002).

The data were subjected to PROC ANOVA and analysed according to a 2 x 2 factorial arrangement of treatments (lipid- $\mathrm{x}$ antioxidant source) and tested for significant differences using the General Linear Model (GLM) procedures of the SAS program (SAS, 1999). Tukey's honest significant difference (HSD) test was used to identify significant differences $(P<0.05)$ between treatments. 


\section{Results and Discussions}

The effect of dietary antioxidant and lipid source on dry matter intake (DMI), apparent digestibility, digestible nutrient and energy content of experimental diets are presented in Table 1.

The DMI of the lambs did not differ significantly $(P>0.05)$ between the various experimental diets. Therefore, feeding level was not a factor that could influence apparent digestibility of the diets. This similar feed intake was expected because the diet nutrient composition (especially NDF content) was the same. Differences in NDF content could affect diet digestibility and rumen fill, two important factors influencing feed intake (McDonald et al., 2002). DMI results over a relatively short period of eight days is, however, less meaningful than those obtained over longer periods and should be interpreted with caution.

Generally, the saturation level of the dietary lipid source had no significant $(P>0.05)$ influence on the apparent digestibility coefficients of nutrients, except for NDF, where the inclusion of unsaturated lipid (soybean oil) in the diet tended to reduce $(P=0.0548)$ the apparent digestibility coefficient, despite the high coefficient of variation $(\mathrm{CV}=15.4 \%)$.

Table 1 Dry matter intake (DMI), apparent digestibility and digestible nutrient content of experimental diets containing different dietary antioxidant and lipid sources fed to lambs (mean values)

\begin{tabular}{|c|c|c|c|c|c|c|c|c|}
\hline \multirow{2}{*}{ Parameter } & \multicolumn{2}{|c|}{$\begin{array}{c}\text { Lipid source } \\
(30 \mathrm{~g} / \mathrm{kg})\end{array}$} & \multicolumn{2}{|c|}{$\begin{array}{l}\text { Antioxidant } \\
(125 \mathrm{~g} / \mathrm{ton})\end{array}$} & \multicolumn{3}{|c|}{$\begin{array}{c}\text { Significance } \\
(P \text {-value })\end{array}$} & \multirow{2}{*}{$\mathrm{CV}^{\#}$} \\
\hline & Saturated & Unsaturated & Synthetic & Natural & $\begin{array}{c}\text { Lipid } \\
\text { source }\end{array}$ & Antioxidant & Interaction & \\
\hline DMI (g/lamb/day) & 1715 & 1706 & 1717 & 1704 & 0.9101 & 0.8662 & 0.9005 & 12.3 \\
\hline \multicolumn{9}{|c|}{ Apparent digestibility coefficients (\%) } \\
\hline $\mathrm{OM}$ & 71.1 & 69.6 & 69.5 & 71.2 & 0.2771 & 0.2198 & 0.0388 & 5.1 \\
\hline Crude protein & 81.0 & 80.2 & 80.3 & 80.9 & 0.3473 & 0.4625 & 0.0888 & 2.7 \\
\hline $\mathrm{NDF}^{*}$ & 47.5 & 42.3 & 42.4 & 47.4 & 0.0548 & 0.0672 & 0.2556 & 15.4 \\
\hline Gross energy & 72.2 & 70.2 & 70.5 & 71.9 & 0.1117 & 0.2755 & 0.0379 & 4.4 \\
\hline \multicolumn{9}{|c|}{ Apparent digestible (\%) } \\
\hline $\mathrm{OM}$ & 63.7 & 62.1 & 62.2 & 63.6 & 0.1891 & 0.2481 & 0.0974 & 5.1 \\
\hline Crude protein & 15.1 & 15.2 & 15.3 & 15.1 & 0.6561 & 0.5804 & $<.0001$ & 2.7 \\
\hline $\mathrm{NDF}^{*}$ & $16.5^{\mathrm{b}}$ & $14.0^{\mathrm{a}}$ & $14.1^{\mathrm{a}}$ & $16.4^{\mathrm{b}}$ & 0.0098 & 0.0159 & 0.4961 & 15.6 \\
\hline $\begin{array}{l}\mathrm{ME}^{*}(\mathrm{MJ} / \mathrm{kg} \\
\mathrm{DM})\end{array}$ & $10.75^{\mathrm{b}}$ & $10.15^{\mathrm{a}}$ & 10.37 & 10.54 & 0.0022 & 0.3431 & 0.1269 & 4.4 \\
\hline
\end{tabular}

${ }^{\mathrm{a}, \mathrm{b}}$ Row means with different superscripts differ significantly $(P<0.05)$ within lipid source or antioxidant means; ${ }^{\#}$ Coefficient of variation (\%);

OM: organic matter; ${ }^{*}$ NDF: neutral detergent fibre; ME (metabolizable energy) $=\mathrm{DE} \times 0.8$ (McDonald et al., 2002).

Lipids with a high UFA content have a negative effect on fibre digestibility due to an antimicrobial effect (Palmquist \& Jenkins, 1980) and lipid coating of the fibres (McDonald et al., 2002). The current study accords with the findings of Beauchemin et al. (2007) that dietary lipid source (unsaturated sunflower oil and saturated tallow) had no effect $(P>0.05)$ on the DM-, CP-, GE- and NDF digestibility. Macleod \& Buchanan-Smith (1972) also found that protein digestibility was not affected by the addition of saturated tallow or unsaturated soybean oil in sheep diets, whereas apparent fibre digestibility was significantly ( $P$ $<0.05$ ) lowered with the inclusion of soybean oil. Studies to assess the effects of lipids on nutrient digestibility in ruminant diets have yielded inconsistent results (Manso et al., 2005). This could be due to a variety of factors such as the level and/or source of dietary lipid and the nature of the basal diet, which in turn influences the effects of lipid on ruminal microbes. Beauchemin et al. (2007) explained that the potentially harmful effects of an unsaturated lipid source on fibre digestion can be minimized by feeding a 
high-concentrate diet low in fibre. Hence, variability of the fibre content of the diets could pose as an explanation for these inconsistent results within the literature.

The comparatively negative effect of the unsaturated lipid source on the apparent digestibility of NDF $(P=0.0548)$ was associated with a lower $(P<0.05)$ digestible NDF content in the experimental diet. Accordingly, unsaturated soybean oil resulted in a significantly lower $(P<0.05)$ ME content in the diet. When ruminant feed is supplemented with lipid rich in UFA, methane emission is reduced (Rasmussen \& Harrison, 2011), possibly by promoting a direct use of hydrogen by hydrolytic bacteria in the rumen (McAllister et al., 1996). Therefore, it may not be justifiable to use the factor of 0.8 (to adjust for methane and urine losses) to calculate dietary ME from the DE content thereof (McDonald et al., 2002). Applying the constant factor may probably over-adjust for the production of methane where unsaturated soybean oil was included in the diet, which could contribute to a misrepresentation of the ME content of the soybean oil, compared to the tallow diet.

The apparent digestibility of NDF tended to be higher $(P=0.0672)$ due to the inclusion of a natural compared to a synthetic antioxidant in the diet (Table 1$)$. This effect was also associated with an increase ( $P$ $<0.05$ ) in dietary digestible NDF content following the natural antioxidant's inclusion. Jami et al. (2012) found that concentrated pomegranate extract (containing polyphenolic compounds) inclusion at $40 \mathrm{~g} / \mathrm{kg}$ within Holstein cow diets increased $(P<0.05)$ the apparent NDF and CP total tract digestibility. This increase in NDF digestibility occurred despite a decrease in some cellulolytic bacterial species. They concluded that this discrepancy might be associated with uncultured cellulolytic species not accounted for in their study. The antioxidant source, however, did not influence $(P>0.05)$ the ME-content of the finishing diet in the present study. Jami et al. (2012) also explained that, although NDF digestibility increased, the utilization of feed energy remained the same. They ascribed this to the polyphenolic compounds contained in the pomegranate extract that increased the methanogenic archaea, which in turn might interfere with the available energy content of the diet.

\section{Conclusions}

Results of the present study seem to indicate that the addition of unsaturated soybean oil compared to saturated beef tallow to lamb finishing diets resulted in a lower apparent digestible NDF and ME content. Estimating ME based on DE x 0.8 may discriminate unfairly against an unsaturated lipid as dietary energy source, by over-estimating ruminal methane losses. A natural antioxidant in the diet was associated with a higher concentration of apparently digestible NDF compared to the synthetic antioxidant. The effects of lipid saturation and antioxidant source on NDF digestibility and diet digestible nutrient content of lamb finishing diets reported here are important, considering the paucity of relevant published research.

\section{Acknowledgements}

The authors wish to acknowledge Meadow Feeds and Biorem Biological Products for their technical and financial support during this study.

\section{References}

AOAC, 2000. Official methods of analysis (17 ${ }^{\text {th }}$ ed.). Volume 1. Association of Official Analytical Chemists, Inc., Gaithersburg, Maryland, USA.

Balcells, J., Aris, A., Serrano, A., Seradj, A.R., Crespo, J. \& Devant, M., 2012. Effects of an extract of plant flavonoids (Bioflavex ${ }^{\circledR}$ ) on rumen fermentation and performance in heifers fed high-concentrate diets. J. Anim. Sci. Published online as doi: 10.2527/jas.2011-4955.

Bauman, D.E., Perfield II, J.W., De Veth, M.J. \& Lock, A.L., 2003. New perspective on lipid digestion and metabolism in ruminants. Proc. Cornell Nutrition Conference. pp. 175-189.

Beauchemin, K.A., McGinn, S.M. \& Petit, H.V., 2007. Methane abatement strategies for cattle: Lipid supplementation of diets. Can. J. Anim. Sci. 87, 431-440.

Cantrell, K.B., Bauer, P.J. \& Ro, K.S., 2010. Utilization of summer legumes as bioenergy feedstock. Biomass and Bioenergy 34, 1961-1967.

Coppock, C.E. \& Wilks, D.L., 1991. Supplemental fat in high-energy rations for lactating cows: effects on intake, digestion, milk yield, and composition. J. Anim. Sci. 69, 3826-3837.

Haak, L., Raes, K., Smet, K., Claeys, E., Paelinck, P. \& De Smet, S., 2006. Effect of dietary antioxidant and fatty acid supply on the oxidative stability of fresh and cooked pork. Meat Sci. 74, 476-486. 
Harris, B., 2003. Using fat in lactating cow ration. University of Florida. IFAS Extention. DS19. pp. 1-8.

Jami, E., Shabtay, A., Nikbachat, M., Yosef, E., Miron, J. \& Mizrahi, I., 2012. Effects of adding a concentrated pomegranate-residue extract to the ration of lactating cows on in vivo digestibility and profile of rumen bacterial population. J. Dairy Sci. 95, 1-10.

LaBrune, H.J., Reinhardt, C.D., Dikeman, M.E. \& Drouillard, J.S., 2008. Effects of grain processing and dietary lipid source on performance, carcass characteristics, plasma fatty acids, and sensory properties of steaks from finishing cattle. J. Anim. Sci. 86, 167-172.

Macleod, G.K. \& Buchanan-Smith, J.G., 1972. Digestibility of hydrogenated tallow, saturated fatty acids and soya bean oil-supplemented diets by sheep. J. Anim. Sci. 4, 890-895.

Manso, T., Castro, T., Mantecón, A.R. \& Jimeno, V., 2005. Effects of palm oil and calcium soaps of palm oil fatty acids in fattening diets on digestibility, performance and chemical body composition of lambs. Anim. Feed Sci. Tech. 127, 175-186.

McAllister, T.A., Okine, E.K., Mathison, G.W. \& Cheng, K.J., 1996. Dietary, environmental and microbiological aspects of methane production in ruminants. Can. J. Anim. Sci. 76, 231-243.

McDonald, P., Edwards, R.A., Greenhalgh, J.F.D. \& Morgan, C.A., 2002. Animal Nutrition. $6^{\text {th }}$ Edition. Pearson Prentice Hall.

Palmquist, D.L. \& Jenkins, T.C., 1980. Fat in lactation rations: review. J. Dairy Sci. 63, 1-14.

Rasmussen, J. \& Harrison, A., 2011. The benefits on supplementary fat in feed rations for ruminants, with particular focus on reducing levels of methane production. ISRN Vet. Sci. pp.1-10.

Ross, J.A. \& Kasum, C.M., 2007. Dietary flavonoids: bioavailability, metabolic effects and safety. Annu. Rev. Nutr. 22, 19-34.

SAS, 1999. Statistical Analysis System user's guide (6 $6^{\text {th }}$ edition). SAS Institute Inc., Raleigh, North Carolina, USA.

Smith, S.A., King, R.E. \& Min, D.B., 2007. Oxidative and thermal stabilities of genetically modified high oleic sunflower oil. Food Chem. 102, 1208-1213.

Van Soest, P.J., Robertson, J.B. \& Lewis, B.A., 1991. Methods of dietary fiber, neutral detergent fiber and non-starch polysaccharides in relation to animal nutrition. J. Dairy Sci. 74, 3583-3597.

Vasta, V., Yanez-Ruiz, D.R., Mele, M., Serra, A., Luciano, G., Lanza, M., Biondi, L. \& Priolo, A., 2010. Bacterial and protozoal communities and fatty acid profile in the rumen of sheep fed a diet containing added tannins. Appl. Environ. Microbiol. 74, 2549-2555.

Winkel-Shirley, B., 2001. Flavonoid biosynthesis. A colourful model for genetics, biochemistry, cell biology, and biotechnology. Plant Physiol. 126, 485-493. 